\title{
Penerapan Model Reciprocal Teaching Untuk Meningkatkan Kemampuan Pemahaman Konsep Matematis Siswa pada Materi Kesebangunan
}

\author{
Alex Tomas ${ }^{1}$, Andika Kusuma Wijaya ${ }^{2}$, Mariyam ${ }^{3}$ \\ Pendidikan Matematika ${ }^{1,3}$, Pendidikan Fisika ${ }^{2}$ STKIP Singkawang, Singkawang, Indonesia \\ t0m4z@ymail.com ${ }^{1}$, andikakusumawijaya1988@gmail.com², mariyam.180488@gmail.com ${ }^{3}$
}

\begin{tabular}{ll}
\hline \hline Kata Kunci: & ABSTRAK \\
Pemahaman Konsep & Penelitian ini bertujuan untuk mengetahui penerapan model \\
Matematis; Reciprocal & Reciprocal Teaching yang mencakup tiga rumusan masalah \\
Teaching & yaitu tentang peningkatan kemampuan pemahaman konsep \\
& matematis, aktivitas siswa, dan respon siswa terhadap model \\
pembelajaran Reciprocal Teaching dalam pembelajaran \\
matematika. Penelitian ini dilakukan pada siswa kelas IX SMP \\
Torsina Singkawang, dengan bentuk penelitian pre- \\
eksperimental dengan rancangan one group pretest-posttest \\
design. Hasil penelitian menunjukkan bahwa : 1) rata-rata \\
posttest sebesar 78,65 lebih tinggi dari hasil rata-rata pretest \\
yaitu 53,39 dan terjadi peningkatan dengan N-gain sebesar \\
0,54 dengan kriteria sedang; 2) Berdasarkan hitungan \\
persentase pada lembar pengamatan aktivitas selama proses \\
pembelajaran diperoleh rata-rata sikap aktif sebesar 90,05\%, \\
sedangkan rata-rata sikap pasif sebesar 9,95\%. Hal ini \\
menunjukan bahwa nilai rata-rata rata-rata sikap aktif lebih \\
besar dibanding dengan nilai rata-rata sifat pasif. Nilai rata- \\
rata persentase sikap aktif berada pada kriteria Sangat Baik \\
yang berarti aktivitas siswa tergolong aktif; 3 Hasil analisis \\
terhadap respon siswa diperoleh rata-rata persentase sebesar \\
80,38\%, berada pada kriteria Baik. Berdasarkan uraian yang \\
telah dikemukakan, pembelajaran dengan model Reciprocal \\
Teaching pada materi Kesebangunan kelas IX SMP Torsina \\
Singkawang dapat meningkatkan kemampuan pemahaman \\
konsep matematis siswa, kemudian siswa tergolong aktif dalam \\
mengikuti pembelajaran dengan model Reciprocal Teaching \\
dan respon siswa terhadap penerapan model Reciprocal \\
Teaching Positif.
\end{tabular}

\section{INTRODUCTION}

Matematika merupakan ilmu dasar yang memiliki peranan penting dalam kehidupan manusia. Dapat dikatakan bahwa perkembangan ilmu pengetahuan dan teknologi dewasa ini dilandasi oleh matematika. Banyak ahli matematika mengatakan matematika adalah ratu sekaligus pelayan semua ilmu pengetahuan. Susilo (2012: v) mengatatakan bahwa sebagai ratu, matematika seolah-olah 
bersinggasana di atas semua ilmu karena matematika berkembang tanpa mendasarkan dirinya pada ilmu-ilmu lainnya. Sebagai pelayan, matematika melayani ilmu-ilmu lainnya yang menggunakan matematika dalam penelitian dan pengembangan dirinya. Agar dapat menguasai dan mencipta teknologi di masa depan diperlukan penguasaan matematika yang kuat. Untuk menguasai matematika diperlukan pemahaman konsep yang baik pula sejak dini. pembelajaran matematika di kelas tidak hanya menitikberatkan pada penguasaan materi untuk menyelesaikan masalah secara matematis. Tetapi juga membuat siswa lebih memahami konsep pada ilmu matematika itu sendiri dan membuat siswa lebih mengenal permasalahan-permasalahan dalam kehidupan sehari-hari yang dapat dipecahkan dengan pengetahuan matematika yang diperoleh siswa di sekolah (Buyung, B., \& Nirawati, R., 2018).

Berdasarkan wawancara dengan guru matematika SMP Torsina Singkawang pada tanggal 10 April 2015 ditemukan hasil belajar siswa kelas IX rendah. Siswa tidak mampu mengerjakan soal-soal dengan benar karena mereka tidak memahami konsep-konsep matematis dengan baik, khususnya pada materi geometri tentang Kesebangunan. Banyak siswa tidak mampu membedakan manakah bangun datar yang sebangun dan mana yang kongruen artinya siswa tidak mampu menyatakan ulang konsep, memberikan contoh dan bukan contoh, dan hal ini membuat siswa tidak mampu menggunakan konsep untuk menyelesaikan masalah yang diberikan. Hal ini berdampak panjang sehingga siswa tidak dapat mengerjakan soal-soal ujian sekolah maupun nasional dengan baik sehingga hasil belajar siswa rendah. Data kolektif hasil Ujian Nasional kota Singkawang pada tahun 2012/2013 dengan rata-rata 4,61 dan pada tahun 2013/2014 dengan rata-rata 4,51. Ini berarti banyak siswa mendapatkan hasil belajar di bawah KKM yang ditetapkan sekolah yaitu 6,8.

Dari observasi penulis menemukan bahwa terdapat beberapa hal yang mempengaruhi rendahnya hasil belajar siswa SMP Torsina Singkawang. Guru mengajar dengan cara menjelaskan, memberi contoh, dan memberikan tugas sebagai latihan, memberikan pekerjaan rumah. Kemudian pertemuan berikutnya memeriksa pekerjaan rumah, menjelaskan materi baru dan mengulangi kebiasaan yang sama. Hal ini merupakan pembelajaran konvensional dimana guru sebagai pusat pembelajaran. Sedangkan siswa hanya duduk mendengarkan penjelasan guru, tidak aktif, belajar individual dan cenderung tidak mengerti. Hanya sedikit siswa yang memang mempunyai kemampuan lebih yang mampu mengikuti penjelasan dari guru. Hal ini menyebabkan kemampuan pemahaman konsep matematis siswa kurang sehingga tidak mampu menyelesaikan soal-soal yang diberikan. Efek lain dari pembelajaran konvensional yaitu siswa cenderung tidak memberikan respon yang baik dalam mengikuti pembelajaran. Siswa malas mengerjakan PR dan tidak menyukai matematika, mengantuk, diam, tidak mampu mengaitkan pelajaran dalam kehidupan sehari-hari, dan sibuk dengan urusan yang tidak berhubungan dengan pelajaran.

Model Reciprocal Teaching merupakan model pembelajaran yang memberikan kesempatan kepada siswa untuk belajar mandiri, kreatif, dan lebih aktif. Dengan keempat strategi yang ada dalam model Reciprocal Teaching siswa akan menjadi aktif dan lebih memahami materi yang dipelajarinya. Menurut Suyitno (dalam Gita, dkk, 2014: 5) mengatakan bahwa pada prinsipnya adalah siswa mempelajari materi secara mandiri, kemudian siswa menyampaikan materi seperti saat guru mengajarkan materi tersebut. Model Reciprocal Teaching memiliki tujuan agar siswa mampu belajar mandiri dan siswa mampu menjelaskan temuannya kepada pihak lain.

Hasil penelitian yang dilakukan oleh Gita, dkk (2014: 8-9) dengan menerapkan model Reciprocal Teaching pada tingkat SD menunjukkan bahwa pemahaman konsep matematika siswa yang mengikuti pembelajaran dengan model Reciprocal Teaching lebih baik dari pada pemahaman konsep matematika siswa yang mengikuti pembelajaran dengan model konvensional. Penelitian yang lain oleh Herman, 
dkk (2014: 17) pada tingkat SMP dengan model Reciprocal Teaching juga menunjukkan hasil yang sama. Oleh karena itu penulis tertarik untuk melakukan penelitian dengan judul "Penerapan model Reciprocal Teaching untuk meningkatkan kemampuan pemahaman konsep matematis siswa pada materi kesebangunan kelas IX SMP Torsina Singkawang” dengan harapan dapat meningkatkan kemampuan pemahaman konsep matematis siswa.

Reciprocal Teaching diperkenalkan untuk pengembangan pembelajaran bahasa (membaca) oleh Annemarie Sullivan Palincsar pada tahun 1982 yang kemudian diperkuat oleh hasil risetnya bersama Ann L. Brown. Keduanya dari University of Illinois. Hasil riset tersebut kemudian dipublikasikan dengan judul Reciprocal Teaching of Comprehension-Fostering and Comprehension Monitoring Activities dan dimuat dalam jurnal Cognition and instruction, 1984, 1 (2), 117-175 (Palincsar and Brown, 1984). Berawal dari praktik pembelajaran bahasa, Reciprocal Teaching ini kemudian banyak juga diterapkan dalam pembelajaran sains, matematika, dan pembelajaran ilmu sosial (Warsono dan Hariyanto, 2013: 86).

Menurut Warsono dan Hariyanto (2013: 71)Reciprocal Teaching merupakan suatu pengajaran dimana para siswa dan guru secara bergantian memimpin dialog terkait strategi dan cara untuk mengkaji suatu bahan ajar tertentu. Palincsar dan Brown (1984: 120) mengatakan bahwa dalam Reciprocal Teaching ini ada empat fase yang wajib dilakukan untuk mencapai tujuan pembelajaran yaitu membuat ringkasan (summarizing), mengajukan pertanyaan (questioning), melakukan klarifikasi (clarifying), memprediksi (predicting).

Reciprocal Teaching ini dikembangkan berdasarkan teori perkembangan kognitif sosial dari Lev Vygotsky dengan ZPDnya (Zone of Proximal Development) dan juga teori Scaffolding dari Jerome S. Bruner. Teori Vygotsky juga dikenal sebagai teori konstruktivisme sosial, yang berarti membangun (to construct) kognitif anak melalui interaksi sosial (Warsono dan Hariyanto, 2013: 58-59). Slavin juga setuju bahwa Reciprocal Teaching merupakan teori pembelajaran yang dikembangkan dengan prinsip teori konstruktivis (Slavin, 2011: 14).

Dalam Permendiknas No. 22 Tahun 2006 tentang standar isi ada beberapa aspek yang menjadi tujuan pembelajaran matematika yang perlu dikembangkan yaitu pemahaman konsep, penalaran, pemecahan masalah, komunikasi dan sikap menghargai matematika. Pemahaman konsep merupakan landasan bagi kemampuan matematis lainnya.

Dalam NCTM 2000 (Walle, 2008: 3) mengatakan para siswa harus belajar matematika dengan pemahaman, secara aktif membangun pengetahuan baru dari pengalaman dan pengetahuan sebelumnya. Rohana (2011: 114) mengatakan bahwa siswa dikatakan memahami suatu konsep atau paham terhadap konsep yang diberikan dalam pembelajaran jika mereka mampu mengemukakan dan menjelaskan suatu konsep yang diperolehnya berdasarkan kata-kata sendiri tidak sekedar menghafal.Dalam Taksonomi Bloom yang telah direvisi oleh Krathwohl mengatakan ada beberapa indikator pemahaman konsep yaitu (a) mampu menafsirkan kembali apa yang diajarkan, (b) memberikan contoh dan bukan contoh, (c) dapat menggolongkan, (d) mampu meringkas atau merangkum kembali materi, (e) membuat kesimpulan, (f) membandingkan, (g) menjelaskan (Warsono dan Hariyanto, 2013: 273).

Kemampuan pemahaman konsep yang dimaksudkan dalam penelitian ini adalah suatu kemampuan siswa dalam mengerjakan soal-soal secara tertulis yang berdasarkan pada indikator kemampuan pemahaman konsep yaitu dapat menyatakan ulang sebuah konsep, memberi contoh dan bukan contoh dari konsep, mengaplikasikan konsep atau algoritma pada pemecahan masalah. Masalah umum penelitian ini yaitu "Bagaimanakah penerapan model pembelajaran Reciprocal Teaching untuk meningkatkan kemampuan pemahaman konsep matematis siswa pada materi Kesebangunan kelas IX SMP Torsina?". Dari rumusan masalah umum maka dirumuskan sub masalah yaitu, 1) Apakah penerapan model Reciprocal Teaching dapat meningkatkan kemampuan pemahaman konsep 
matematis siswa pada materi Kesebangunan kelas IX SMP Torsina?, 2) Bagaimanakah aktivitas siswa dengan diterapkannya model Reciprocal Teaching untuk meningkatkan pemahaman konsep matematis siswa pada materi Kesebangunan kelas IX SMP Torsina?, 3) Bagaimanakah respon siswa dengan diterapkannya model Reciprocal Teaching untuk meningkatkan pemahaman konsep matematis siswa pada materi Kesebangunan kelas IX SMP Torsina?. Penelitian ini bertujuan 1) untuk mengetahui penerapan model Reciprocal Teaching dapat meningkatkan kemampuan pemahaman konsep matematis siswa pada materi Kesebangunan kelas IX SMP Torsina. 2) Aktivitas siswa dengan diterapkannya model Reciprocal Teaching untuk meningkatkan pemahaman konsep matematis siswa pada materi Kesebangunan kelas IX SMP Torsina.

3) Untuk mengetahui respon siswa dengan diterapkannya model Reciprocal Teaching untuk meningkatkan pemahaman konsep matematis siswa pada materi Kesebangunan kelas IX SMP Torsina.

\section{METHOD}

Penelitian ini merupakan jenis penelitian pre-eksperimen karena peneliti hanya memberikan perlakuan pada kelas eksperimen. Dalam penelitian ini peneliti memberikan tes awal kemudian memberikan perlakuan dan tes akhir pada satu kelas. Jadi desain dalam penelitian ini adalah one-group pretestposttest design. Populasi dalam penelitian ini adalah kelas IX A dan IX B SMP Torsina Singkawang. Dari populasi tersebut diambil satu kelas yaitu IX A dengan teknik purposive sampling, karena penelitian dilakukan dengan lebih mengutamakan tujuan penelitian daripada sifat populasi dalam menentukan sampel penelitian (Bungin, 2006: 115).

Teknik pengumpulan data yang dipergunakan dalam penelitian ini sebagai berikut: (a) Teknik pengukuran dalam penelitian ini adalah dengan menggunakan tes. Tes dilakukan untuk mengetahui kemampuan pemahaman konsep matematis siswa sebelum dan setelah diterapkannya model Reciprocal Teaching, (b) Teknik observasi untuk mengetahui aktivitas belajar siswa menggunakan lembar observasi., (c) Teknik komunikasi tidak langsung untuk melihat respon siswa berupa angket yang disebarkan kepada siswa.

Teknik analisis data yang digunakan sebagai berikut: (1) untuk menjawab sub masalah pertama: memberikan skor jawaban siswa sesuai dengan skor alternatif jawaban dan pedoman penskoran yang digunakan, memberikan nilai, dan menghitung rata-rata pre-test dan post-test kelas eksperimen, menggunakan perhitungan gain score untuk mengetahui peningkatan hasil test. (2) Untuk menjawab sub masalah kedua tentang aktivitas siswa setelah menerapkan model Reciprocal Teaching maka dilakukan: menghitung jumlah frekuensi siswa yang melakukan indikator aktivitas setiap kategori, menghitung persentase frekuensi aktivitas belajar siswa, dan mengkriteriakan aktivitas belajar siswa melalui hasil rata-rata perolehan persentase seluruh pertemuan yang dilaksanakan. (3) Untuk menjawab sub masalah ketiga, data angket respon siswa akan dianalisis menggunakan statistik deskriptif. Angket respon siswa berupa tanggapan terhadap pertanyaan atau pernyataan yang diukur menggunakan skala Likert.

\section{RESULTS AND DISCUSSIONS}

\section{Kemampuan Pemahaman Konsep Matematis Siswa}

Adapun rangkuman hasil pre-test dan post-test kelas ekperimen dalam Tabel 1.

Tabel 1. Nilai Pre-test dan Post-test Kelas Eksperimen

\begin{tabular}{llll}
\hline Indikator & $\begin{array}{l}\text { Pre-test } \\
(\%)\end{array}$ & Post-test $(\%)$ & $\begin{array}{l}\text { Peningkatan } \\
(\%)\end{array}$ \\
\hline A & $\mathbf{5 4 , 6 9}$ & $\mathbf{7 6 , 5 6}$ & $\mathbf{2 1 , 8 8}$ \\
\hline
\end{tabular}




\begin{tabular}{llll}
\hline B & $\mathbf{6 0 , 4 2}$ & $\mathbf{7 9 , 1 7}$ & 18,75 \\
\hline $\mathrm{C}$ & $\mathbf{4 7 , 9 2}$ & $\mathbf{8 5 , 4 2}$ & $\mathbf{3 7 , 5 0}$ \\
\hline
\end{tabular}

Berdasarkan data dalam Tabel 1 tersebut dapat dilihat bahwa terjadi peningkatan kemampuan pemahaman konsep matematis siswa pada kelas eksperimen. Kemampuan pemahaman konsep matematis siswa dengan indikator menyatakan ulang konsep matematis siswa mengalami peningkatan 21,88\%, memberikan contoh dan bukan contoh meningkat $18,75 \%$, dan mengaplikasikan konsep pada pemecahan masalah meningkat sebesar 37,50\%. Untuk melihat efektifitas penggunaan Model Reciprocal Teaching, maka dilakukan uji N-Gain yang hasilnya disajikan dalam Tabel 2.

Tabel 2. Nilai N-Gain Kelas Eksperimen

\begin{tabular}{ccc}
\hline Kelas & Nilai N-Gain & Kriteria \\
\hline Eksperimen & 0,54 & Sedang \\
\hline & & (Hake : 1999)
\end{tabular}

Berdasarkan hasil perhitungan dengan menggunakan rumus Gain Ternormalisasi maka diperoleh nilai 0,54 dengan kriteria sedang. Hal ini menunjukan bahwa kemampuan pemahaman konsep matematis siswa meningkat setelah diberikan perlakuan dengan menggunakan model Reciprocal Teaching. Dengan demikian Ha diterima dan Ho ditolak.

Faktor yang menyebabkan meningkatnya kemampuan pemahaman konsep matematis siswa dengan menggunakan model Reciprocal Teaching adalah rangkaian kegiatan pembelajaran yang menekankan pada proses pembelajaran mandiri dan kerjasama (Scaffolding) sehingga siswa dapat berdiskusi secara kelompok dengan baik.

\section{Aktivitas Belajar Siswa dalam Model Pembelajaran Reciprocal Teaching}

Berdasarkan enam kategori pembelajaran yang dikembangkan menjadi 15 indikator yang akan di observasi dengan model Reciprocal Teaching maka diringkas hasil observasi pertemuan pertama dan kedua dapat dilihat pada Tabel 3.

Tabel 3. Aktivitas Belajar Siswa Proses Pembelajaran Reciprocal Teaching

\begin{tabular}{lcc}
\hline \multicolumn{1}{c}{ Pertemuan } & Perilaku Siswa Aktif & Perilaku Siswa Pasif \\
\hline Pertama & $90,98 \%$ & $9,02 \%$ \\
Kedua & $89,13 \%$ & $10,87 \%$ \\
\hline Rata-rata & $90,05 \%$ & $9,95 \%$ \\
\hline Kategori & Sangat Baik & Kurang \\
\hline
\end{tabular}

Berdasarkan hitungan persentase pada lembar pengamatan aktivitas selama proses pembelajaran diperoleh rata-rata sikap aktif sebesar 90,05\%, sedangkan rata-rata sikap pasif sebesar 9,95\%. Hal ini menunjukan bahwa nilai rata-rata sikap aktif lebih besar dibanding dengan nilai rata-rata sikap pasif. Nilai rata-rata persentase aktif berada pada kriteria sangat baik. Dengan demikian, dapat disimpulkan bahwa siswa tergolong aktif pada saat proses pembelajaran dengan menggunakan model Reciprocal Teaching.

Pada pembelajaran konvensional siswa hanya duduk manis mendengar saja, tetapi dengan menerapkan Reciprocal Teaching siswa rata-rata menjadi out of the box, siswa menjadi aktif dengan kelompok dan bisa menunjukkan sikap berdiskusi, berpartisipasi, mengerjakan tugas dan mengumpulkan tepat waktu.

\section{Respon Siswa dalam Model Pembelajaran Reciprocal Teaching}


Tabel 3. Aktivitas Belajar Siswa Proses Pembelajaran Reciprocal Teaching

\begin{tabular}{clllll}
\hline & \multicolumn{5}{c}{ Kategori Pernyataan } \\
\cline { 2 - 5 } & $\mathrm{SS}$ & $\mathrm{S}$ & $\mathrm{R}$ & $\mathrm{TS}$ & $\mathrm{STS}$ \\
\hline $\begin{array}{c}\text { Persentase siswa yang memilih } \\
\text { suatu option (\%) }\end{array}$ & $28,13 \%$ & $50 \%$ & $20,63 \%$ & $1,25 \%$ & $0 \%$ \\
\hline
\end{tabular}

Berdasarkan hasil jawaban siswa pada angket diperoleh hasil perhitungan yang memilih SS (Sangat Setuju) dan S (Setuju) sebesar 78,13\% dan yang memilih R (Ragu), TS (Tidak Setuju), dan STS (Sangat Tidak Setuju) sebesar 21,88 \%. Persentase yang memilih SS dan S lebih besar dari persentase yang memilih R, TS, dan STS maka dapat dikatakan bahwa secara keseluruhan respon siswa positif dan berada pada kriteria Baik. Respon positif berarti siswa senang belajar dengan menggunakan model Reciprocal Teaching.

Salah satu faktor yang yang mempengaruhi kualitas belajar adalah sikap. Seorang anak yang memiliki sikap positif terhadap belajar, maka anak tersebut akan memperoleh kesuksesan dalam belajar (Rasyid dan Mansur, 2009: 16). Jadi sikap siswa setelah mengikuti pelajaran harus lebih positif dibanding sebelum mengikuti pelajaran. Perubahan ini merupakan salah satu indikator keberhasilan guru dalam melaksanakan proses belajar mengajar (Rasyid dan Mansur, 2009: 17). Model Reciprocal Teaching menekankan 4 fase yaitu membuat ringkasan (summarizing), mengajukan pertanyaan (questioning), melakukan klarifikasi (clarifying), memprediksi (predicting) sehingga siswa sangat menikmati proses dan pada akhirnya memberikan respon yang positif/baik.

\section{CONCLUSION AND SUGGESTION}

Dari hasil penelitian dapat disimpulkan bahwa:

1) kemampuan pemahaman konsep matematis siswa dengan indikator menyatakan ulang konsep matematis siswa mengalami peningkatan $21,88 \%$, memberikan contoh dan bukan contoh meningkat $18,75 \%$, dan mengaplikasikan konsep pada pemecahan masalah meningkat sebesar $37,50 \%$. Selanjutnya berdasarkan hasil perhitungan dengan menggunakan rumus $\mathrm{N}$-gain terdapat peningkatan kemampuan pemahaman konsep matematis siswa kelas IX di SMP Torsina Singkawang pada materi Kesebangunan dengan penerapan model Reciprocal Teaching sebesar 0,54 dengan kriteria sedang. Rata-rata persentase sikap aktif siswa yaitu 90,05\%,

2) rata-rata persentase sikap pasif siswa 9,95\%. Rata-rata persentase sikap aktif lebih besar dari ratarata persentase sikap pasif maka dapat disimpulkan aktivitas siswa selama pembelajaran dengan menggunakan model Reciprocal Teaching tergolong aktif dan pada kriteria sangat baik.

3) Persentase yang memilih SS dan S yaitu $78,13 \%$ lebih besar dari persentase yang memilih R, TS, dan STS yaitu $21,88 \%$, maka dapat dikatakan bahwa secara keseluruhan respon siswa positif dan berada pada kriteria Baik. Respon positif berarti siswa senang belajar dengan menggunakan model Reciprocal Teaching

Berdasarkan pembahasan dan hasil penelitian serta kesimpulan yang telah didapat, beberapa saran yang dapat diberikan yaitu : para guru dapat menjadikan model pembelajaran Reciprocal Teaching sebagai alternatif model belajar untuk meningkatkan kemampuan pemahaman konsep matematis siswa, guru dapat menjadikan penelitian ini sebagai referensi untuk melakukan penelitian, bagi peneliti lain yang ingin melakukan penelitian yang sama dapat memanfaatkan penelitian ini sebagai referensi. Peneliti harus mempersiapkan instrumen dengan sebaik mungkin dan mengatur waktu dengan tepat agar penerapan model pembelajaran Reciprocal Teaching dapat diterapkan dengan baik. 
Penulis mengucapkan terima kasih yang sebesarnya kepada dosen pembimbing yang mendukung sehingga artikel ini bisa diselesaikan dengan baik. Terima kasih juga kepada dosen yang mengelola jurnal publikasi yang telah membantu mempublis artikel ini. Terima kasih kepada seluruh pihak STIKIP yang telah membantu baik langsung maupun tidak langsung.

\section{REFERENCES}

Bungin, Burhan. 2005. Metode Penelitain Kuantitatif. Kencana: Jakarta.

Buyung, B., \& Nirawati, R. (2018). PENGARUH KARAKTER KERJA KERAS TERHADAP KEMAMPUAN LITERASI MATEMATIS SISWA MELALUI MODEL DISCOVERY LEARNING. JPMI (Jurnal Pendidikan Matematika Indonesia), 3(1), 21-25.

Gita, dkk (2014). "Pengaruh Model Reciprocal Teaching Terhadap Pemahaman Konsep Dan Motivasi Belajar Matematika Siswa Kelas V SD" e-Journal Program Pascasarjana, Universitas Pendidikan Ganesha Program Studi Pendidikan Dasar. Volume 4 (2014).

Hake, Ricard. 1999. Analizing Change/Gain Scores. Dept. Of Physics, Indiana University 24245 Hatterras Street, Woodland Hills, CA, 91367 USA

Herman, dkk. (2014). "Penerapan Model Reciprocal Teaching Pada Pembelajaran Matematika Siswa Kelas VIII Smpn 26 Padang” Jurnal Pendidikan Matematika, FMIPA UNP. Vol. 3 No. 1 (2014): Part 2 Hal 13-17.

Kemendikbud. (2006) Permendikbud No. 22 tentang Standar Isi. Jakarta: Kemendikbud

Palincsar and Brown, (1984). "Reciprocal Teaching of Comprehension Fostering and Comprehension Monitoring Activities" Cognition and Instruction, 1984, 1 (2) 117-175.

Rasyid dan Mansyur. 2009. Penilaian Hasil Belajar. Bandung: Wacana Prima.

Rohana. (2011). "Pengaruh Pembelajaran Berbasis Masalah Terhadap Pemahaman Konsep Mahasiswa Prodi Pendidikan Matematika FKIP Universitas PGRI Palembang” Jurnal Prosiding Seminar Nasional Pendidikan,Universitas PGRI Palembang.

Slavin, RE. 2011.Psikologi Pendidikan Teori dan Praktik. Jilid 2, Jakarta: Indeks.

Susilo, Frans. 2012. Landasan Matematika.Yogyakarta: Graha Ilmu.

Walle, John AVD. 2008. Matematika Sekolah Dasar dan Menengah. Jilid 1,Jakarta: Erlangga.

Warsono dan Hariyanto. 2013. Pembelajaran Aktif Teori dan Asesmen. Bandung: Rosdakarya. 